\title{
PENGEMBANGAN MULTIMEDIA INTERAKTIF MACROMEDIA FLASH PROFESIONAL 8 PADA PEMBELAJARAN AL-QUR'AN HADIS KELAS X SEMESTER GENAP DI MAN 1 YOGYAKARTA
}

\author{
Oleh. \\ Moh. Solikul Hadi, M. Sayyidul Abrori, Dwi Noviatul Zahra. \\ Universitas Islam Negeri Sunan Kalijaga Yogyakarta. \\ e-mail: hadialsultoni@gmail.com, arori400@gmail.com, \\ dwinoviatulzahra11@gmail.com.
}

\begin{abstract}
Development of the Qur'an and Hadith learning media at class XMA through interactive multimedia macromedia flash is based on the reality that several students are lazy in studying the Qur'an and Hadith and that causes the students' learning outcomes are decreasing. This case is caused by variety of factors, some of them are the teaching methods used by the teachers are still conventional, the learning medias used by the teachers are less interesting, and the sources they used are limited. The purpose of this interactive media development is to produce learning media to study the Qur'an and Hadith at class X MA to improve students' learning outcomes. The research method used in this research is using Research and Development method with research plans adapted from Dick and Carey model. The steps of this development are consisting of 9 stages. The result of this research shows that the product of interactive multimedia on learning the Qur'an and Hadith at class X MA fulfill the properness criteria by which the test result from media experts reaches properness level at $88 \%$, from lesson experts reaches properness level at 98,75\%, and from the Qur'an and Hadith teacher reaches properness level at 91,25\%. Field trial result by using experiment research that is by using control and experiment class shows several significant differences that is the average results of post-test is higher than control class in sig. 0,971 higher than 0,05.
\end{abstract}

Key words: Interactive Multimedia, The Qur'an And Hadith, Learning Outcomes

\begin{abstract}
Abstrak
Pengembangan media pembelajaran Al-Qur'an hadist kelas X MA melalui multimedia interaktif macromedia flash didasarkan pada realitas di lapangan bahwa siswa malas belajar Al-Qur'an hadist yang mengakibatkan hasil belajar siswa menurun. Hal tersebut disebabkan oleh beberapa faktor diantaranya cara mengajar guru yang masih bersifat konvensional, media pembelajaran yang digunakan guru kurang menarik serta sumber belajar yang digunakan guru terbatas. Tujuan pengembangan multimedia interaktif ini adalah menghasilkan
\end{abstract}


produk media pembelajaran Al-Qur'an hadist kelas X MA untuk meningkatkan hasil belajar siswa. Metode penelitian yang digunakan dalam penelitian ini menggunakan metode Research and Development dengan rancangan penelitian yang diadaptasi dari model Dick and Carey. Hasil penelitian ini menunjukkan bahwa produk multimedia interaktif Al-Qur'an hadist kelas X MA memenuhi kriteria kelayakan dengan hasil uji ahli media mencapai tingkatkan kelayakan $88 \%$, ahli materi mencapai tingkat kelayakan sebesar 98,75\% dan guru mata pelajaran Al-Qur'an hadist mencapai kelayakan sebesar 91,25\%. Hasil uji coba lapangan dengan menggunakan kelas kontrol dan kelas eksperimen di dapatkan hasil terdapat perbedaan yang signifikan antara hasil rata- rata post test kelas eksperimen lebih tinggi dari kelas kontrol dengan sig. Sebesar 0,971 lebih besar dari 0,05.

\section{Kata Kunci : Multimedia interaktif, Al-Qur'an hadist, hasil belajar}

\section{A. PENDAHULUAN}

Al-Qur'an dan Hadis merupakan dua sumber utama Islam yang menjadi pedoman hidup manusia di dunia dan akhirat. Kesalahan dalam mempelajari dan memahami dua sumber tersebut akan menghancurkan kehidupan umat manusia sendiri. Pentingnya mempelajari Al-Qur'an hadis di sekolah adalah untuk mengenalkan kepada manusia bahwa segala yang ada di bumi dan dilangit, dan segala syariat Islam semuanya telah diatur di dalamnya.

Pentingnya mempelajari AlQur'an Hadis tidak menjamin siswa senang mempelajarinya, hal tersebut dikarenakan bahasa yang digunakan dalam Al-Qur'an dan Hadis adalah bahasa Arab. ketika seorang siswa Madrasah Aliyah (MA) diminta untuk menghafal satu ayat pendek dalam Alquran atau satu hadis Nabi, mayoritas dari mereka bisa menghafalnya dengan lancar, tetapi, jika diminta untuk memilah kosa kata ayat dan hadis, menerjemahkan dan mengemukakan sekilas kandungan ayat dan hadis tersebut, dapat dipastikan mayoritas tidak bisa melakukannya. ${ }^{1}$

Permasalahan tersebut juga terjadi di kelas X MAN 1 Yogyakarta Berdasarkan hasil observasi sementara yang dilakukan oleh peneliti, ditemukan permasalahan yakni siswa malas belajar Al-Qur'an Hadis dikelas. Malasnya siswa dalam belajar utamanya dalam menghafalkan beberapa ayat Al-Qur'an dan Hadis, siswa merasa kesulitan dalam memilahmilah dan mengartikan kosa kata ayat maupun Hadis. Disamping itu siswa juga merasa kesulitan jika diminta untuk mengemukakan kandungan atau makna yang tersirat pada ayat AlQur'an/ Hadis.

Permasalahan diatas muncul karena disebabkan oleh beberapa faktor baik dari tenaga pendidik maupun media yang digunakan untuk menyampaikan materi pembelajaran.

1 Muhammad Nasir, Pengembangan Model Pembelajaran Al-Qur'an Hadits Madrasah Aliyah (MA) di Samarinda dalam Jurnal “Al-Qalam”, Vol. 20 No 1 Juni 2014. 
Berdasarkan observasi sementara yang dilakukan, media pembelajaran $\mathrm{Al}$ Qur'an Hadis yang digunakan oleh guru dan siswa kelas $\mathrm{X}$ MAN 1 Yogyakarta berupa buku ajar terbitan Kementrian Agama 2014, LKS, PowerPoint yang dibuat mandiri oleh guru dan video yang menunjang. Hasil observasi peneliti terhadap media pembelajaran tersebut menemukan beberapa masalah, antara lain: 1) sajian materi kurang variatif; 2) ilustrasi gambar masih terlihat jarang; 3); penyajian materi lebih banyak berupa teks monoton; 4) video yang digunakan hanya berupa tayangan film saja.

Idealnya kegiatan belajar mengajar di tingkat MAN I Yogyakarta khususnya mata pelajaran Al-Qur'an Hadis telah menggunakan multimedia interaktif. Media pembelajaran adalah alat bantu pada proses belajar dalam rangka komunikasi interaktif guru dan siswa dalam proses pembelajaran. ${ }^{2}$ Manfaat media pembelajaran adalah (1) penyampaian materi pembelajaran dapat diseragamkan; (2) proses pembelajaran menjadi lebih menarik; (3) proses belajar siswa menjadi interaktif, peran guru diubah menjadi lebih positif dan produktif. ${ }^{3}$ Pentingnya media pembelajaran menurut yakni bersifat menyalurkan pesan dan dapat merangsang pikiran, perasaan dan kemauan audien (siswa) sehingga dapat

2 Nana Syaodih Sukmadinata, DasarDasar Proses Belajar Mengajar, (Bandung, SInar Baru Algesindo), hlm.19

3 Nassar, Merancang Pembelajaran AKtif dan Kontekstual, (Jakarta: Grasindo, 2006), hlm. 19 mendorong proses belajar mengajar pada dirinya ${ }^{4}$

Merujuk fenomena tersebut, peneliti ingin mengembangkan media pembelajaran yang digunakan di MAN 1 Yogyakarta dengan menggunakan pembelajaran berbasis multimedia interaktif. Metode pengembangan media yang berbasis multimedia interaktif ini disesuaikan dengan Kompetensi Inti (KI), Kompetensi Dasar (KD), dan indicator pembelajaran pada mata pelajaran AlQur'an Hadis di jenjang Madrasah Aliyah.

Pengembangan multimedia interaktif menggunakan macromedia Flash 8 ini diharapkan mampu membantu siswa dalam meningkatkan hasil belajar siswa pada mata pelajaran Al-Qur'an Hadis dalam aspek pengetahuan (kognitif) dan psikomotoriknya. Disamping itu membantu guru dalam menyampaikan materi sehingga pembelajran AlQur'an hadis menjadi lebih mudah dipahami, efektif dan menarik.

\section{B. METODE PENELITIAN}

Metode penelitian yang digunakan peneliti dalam penelitian pengembangan multimedia interaktif ini yakni dengan menggunakan metode penelitian Research and Development ( $R \& D) . \quad R \& D$ adalah prosedur penelitian dengan tujuan untuk menghasilkan produk dan menguji keefektifan produk tersebut atau langkah untuk mengembangkan suatu

${ }^{4}$ Cecep Kustandi, Media Pembelajaran Manual dan Digital, (Bogor, Ghalia Indonesia, 2011), hlm. 7. 
produk baru atau menyempurnakan produk yang telah ada, yang dapat dipertanggungjawabkan, dan menguji keefektifannya. ${ }^{5}$

Penelitian ini menggunakan model prosedural. Model prosedural adalah model yang bersifat deskriptif, menunjukkan langkah-langkah yang harus diikuti untuk menghasilkan produk. ${ }^{6}$ Model prosedural yang digunakan dalam pengembangan multimedia interaktif ini adalah model Dick \& Carey. Ada sepuluh langkah dalam model pengembangan Dick \& Carey, yaitu:

a. Mengidentifikasi Tujuan Umum Pembelajaran (Identifying Instructional Goals)

b. Analisis pembelajaran (Conducting Instructional Analysis)

c. Analisis Kebiasaan dan Karakteristik Peserta Didik (Identifying Entry Behaviors, Characteristics)

d. Merumuskan Tujuan Khusus pembelajaran (Writing Performance Objective)

e. Mengembangkan Instrument Tes Acuan Patokan (Developing Criterion-Referenced Test)

f. Mengembangkan Strategi Pembelajaran (Developing Instructional Strategy)

g. Mengembangkan dan Memilih Bahan Pembelajaran (Developing and Selecting Instruction)

5 Nana Syaodih Sukmadinata, Metode Penelitian Pendidikan, (Bandung: PT Remaja Rosdakarya, 2011), hlm. 164.

${ }^{6}$ Sugiono, Metode Penelitian Kualitatif, Kuantitatif dan $R \& D$, (Bandung, Alfabeta, 2011), hlm. 297. h. Merancang dan Melakukan Evaluasi Formatif (Designing and Conducting Formative Evaluation).

i. Melakukan Revisi (Revising Instruction)

j. Merancang dan Melakukan Evaluasi Sumatif (Designing and Conducting Summative

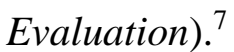

Uji coba dilakukan dalam rangka mengetahui tingkat validitas, dan efektifitas produk, maka perlunya dilakukan kegiatan uji validasi dan uji coba lapangan yang dilaksanakan melalui beberapa tahap, uji validasi: (1) Ahli materi (2) Ahli media 3) Guru mata pelajaran Al-Qur'an Hadis. Uji coba dilaksanakan melalui beberapa tahapan yakni: (1) uji coba perorangan 4 orang (2) uji coba kelompok kecil antara 10 siswa, (3) dan uji coba lapangan 25 siswa.

Instrumen pengumpul data yakni berupa wawancara, angket dan tes perolehan hasil belajar, yakni tes prestasi yang digunakan untuk mengukur pencapaian seseorang setelah mempelajari sesuatu. data dianalisis menggunakan tiga teknik analisis data yakni: analisis isi pembelajaran, analisis deskriptif, dan Uji-T.

\section{KAJIAN TEORI}

1. Teori Belajar dan Pembelajaran

7 Emzir, Metodologi Penelitian Pendidikan Kuantitatif dan Kualitatif, (PT. Raja Grafindo Persada: Jakarta, 2015), hlm. 275-277. 
Pengembangan media pembelajaran Al- Qur'an Hadis Materi ikhlas dalam beribadah untuk kelas $\mathrm{X}$ MA dikembangkan mengacu pada teori Edgar Dale yang terkenal dengan Cone of Experience bahwa manusia mempunyai daya kemampuan daya serap yakni kemapuan pengecapan $2,5 \%$, perabaan $3,5 \%$, penciuman $1 \%$, pendengaran $11 \%$ dan penglihatan $82 \%^{8}$

Menurut teori konstruktivistik belajar merupakan suatu proses mengasimilasikan dan mengkaitkan pengalaman atau pelajaran yang dipelajari dengan pengertian yang sudah dimilikinya, sehingga pengetahuannya dapat dikembangkan. Prinsip mendasar pada teori konstruktivistik adalah guru tidak hanya memberikan pengetahuan kepada siswa, namun siswa juga harus berperan aktif membangun sendiri pengetahuan di dalam memorinya. ${ }^{9}$

Adapun tujuan dari teori konstruktivistik adalah sebagai berikut:

1. Adanya motivasi untuk siswa bahwa belajar adalah tanggung jawab siswa itu sendiri.

2. Mengembangkan kemampuan siswa untuk mengejukan pertanyaan dan mencari sendiri pertanyaannya.

3. Membantu siswa untuk mengembangkan pengertian dan

8 Daryanto, Media Pembelajaran: Peranannya Sangat Penting dalam Mencapai Tujuan Pembelajaran, (Yogyakarta: Gava Media, 2010), hlm. 13-14.

9 Ratna Wilis Dahar, Teori-Teori Belajar dan Pembelajaran, (Jakarta: Erlangga, 2013), hlm, 236. pemahaman konsep secara lengkap.

4. Mengembangkan kemampuan siswa untuk menjadi pemikir yang mandiri.

5. Lebih menekankan pada proses dari pada hasil ${ }^{10}$

\section{Pengembangan Media dalam \\ Pembelajaran}

Pengembangan

media pembelajaran adalah serangkaian proses atau kegiatan yang dilakukan untuk menghasilkan suatu media pembelajaran berdasarkan teori pengembangan yang telah ada. ${ }^{11}$ Manfaat media pembelajaran bagi guru dan siswa menurut Hujair diantaranya: (1) memberikan pedoman dan arah untuk mencapai tujuan, (2) memberikan kerangka sistematis mengajar secara baik, meningkatkan kualitas pembelajaran, (4) meningkatkan motivasi belajar peserta didik, (5) merangsang peserta didik untuk berfikir dan beranalisis, (6) peserta didik dapat memahami materi pelajaran dengan sistematis yang disajikan guru lewat media pembelajaran (Hujair AH Sanaky, 2009:5)

Untuk menghasilkan media yang layak secara teoritis, media harus ditelaah oleh ahli media, ahli materi dan guru mata pelajaran Al-Qur'an Hadis. Kelayakan teoritis media ditinjau dari kelayakan materi dan

10 Syaiful Sagala,Konsep dan Makna Pembelajaran, (Bandung: Alfabeta, 2009),hlm.146.

${ }^{11}$ Arief S Sadiman, Media Pendidikan:

Pengertian, Pengembangan dan

Pemanfaatannya. (Jakarta: Raja Grafindo, 2014), hlm. 99 
media. Kelayakan materi meliputi kesesuaian isi dengan tujuan pembelajaran. Sedangkan kelayakan media meliputi format media, kualitas media, dan kesuaian konsep. Berdasarkan kelayakan tersebut maka akan dihasilkan media pembelajaran yang layak digunakan dalam proses pembelajaran.

\section{Multimedia Interaktif}

Multimedia adalah seperangkat media yang relevan dalam hubungannya dengan tujuan-tujuan instruksional. ${ }^{12}$ Sedangkan menurut Deni Darmawan, multimedia sebagai alat yang dapat menciptakan presentasi yang dinamis dan interaktif yang mengkombinasikan teks, grafik, animasi, audio dan video. ${ }^{13}$

Multimedia terbagi menjadi dua kategori, yaitu: multimedia linier dan multimedia interaktif. Multimedia interaktif adalah suatu multimedia yang dilengkapi dengan alat pengontrol yang dapat dioperasikan oleh pengguna, sehingga pengguna dapat memilih apa yang dikehendaki untuk proses selanjutnya. Contoh multimedia interaktif adalah multimedia pembelajaran interaktif, aplikasi game, dan lain-lain. ${ }^{14}$

Beberapa alasan yang menjadi penguat multimedia interaktif menjadi pendukung pembelajaran, antara lain:

12 Oemar Hamalik, Media Pendidikan, (Bandung: PT. Citra Aditya Bakti, 1994), hlm.187.

13 Deni Darmawan, Teknologi Pembelajaran, (Bandung: Rosdakarya, 2011), hlm. 36.

14 Munir, Multimedia: Konsep dan Aplikasi dalam Pendidikan, (Bandung: Alfabeta, 2012), hlm.110.
1. Pesan yang disampaikan dalam materi lebih terasa hidup

2. Merangsang berbagai indera sehingga terjadi interaksi antar indera

3. Visualisasi dalam bentuk teks, gambar, audio, video maupun animasi akan lebih dapat diingat dan ditangkap peserta didik. ${ }^{15}$ Multimedia interaktif yang akan dikembangkan peneliti melalui program macromedia flash profesional 8 pada mata pelajaran Al-Qur'an Hadis kelas X semester genap di dalammnya memadukan antara teks, gambar, audio, music, animasi dan suara dalam satu kesatuann yang saling mendukung guna tercapainya pembelajaran.

\section{Macromedia Flash Profesional}

Pada latar belakang diatas telah disinggung sedikit mengenai Macromedia Flash Professional 8 yang merupakan sebuah software dapat digunakan sebagai salah satu media untuk pembelajaran, karena selain kemampuan animasi yang menonjol, program ini bisa digunakan untuk membuat presentasi, simulasi, permainan navitasi situs web., aplikasi web., iklan dan sebagainya. ${ }^{16}$

\section{Pembelajaran Al-Qur'an Hadis}

Secara substansial, mata pelajaran Al-Qur'an Hadis memiliki kontribusi dalam memberikan motivasi kepada peserta didik untuk mempelajari dan mempraktikkan ajaran dan nilai- nilai yang terkandung dalam

15 Munir, Multimedia: Konsep dan Aplikasi dalam Pendidikan, ...., hlm.110.

16 Nurdin Ardiansyah, Macromedia Flash Profesional 8: Sebuah Tutorial Flash untuk Pemula, (Kalimantan Barat: Sekadau, 2013), hlm.6. 
Al-Qur'an-Hadis sebagai sumber utama ajaran Islam dan sekaligus menjadi pegangan dan pedoman hidup dalam kehidupan sehari- hari. ${ }^{17}$

Tujuan mata pelajaran Al-Qur'an Hadis adalah: a) Untuk meningkatkan kecintaan peserta didik terhadap AlQur'an dan Hadis, b) Membekali peserta didik dengan dalil- dalil yang terdapat dalam Al-Qur'an dan Hadis sebagai pedoman dalam menyikapi dan menghadapi kehidupan, c) Meningkapkan pemahaman dan pengalaman isi kandungan Al-Qur'an dan Hadis yang dilandasi oleh dasardasar keilmuan tentang Al-Qur'an dan Hadis. ${ }^{18}$

\section{Hasil Belajar}

Hasil belajar adalah kemampuan yang dimiliki peserta didik setelah menerima pengalaman belajarnya. 19 Hasil belajar juga merupakan prestasi yang dicapai peserta didik dalam bidang tertentu dan untuk memperolehnya, perlu menggunakan strandar sebagai pengukurannya. Kriteria hasil belajar peserta didik yang biasa digunakan adalah dengn KKM (Kriteria Ketuntasan Minimal). Nilai KKM pada mata pelajaran Al-Qur'an Hadis di MAN 1 Yogyakarta adalah 78. Berdasarkan hasil wawancara dengan Bapak Zuliadi kriteria hasil belajar di MAN 1 Yogyakarta:

${ }^{17}$ Lampiran Keputusan Menteri Agama Republik Indonesia, No.165 Tahun 2014 tentang tentang Kurikulum Madrasah 2013 Pendidikan Agama Islam dan Bahasa Arab, hlm.49.

${ }^{18}$ Ibid, hlm.52.

${ }^{19}$ Nana Sudjana, Penilaian Hasil Proses Belajar Mengajar, (Bandung: Rosdakarya, 2014), hlm.22.
1. Prestasi belajar tinggi, jika peserta didik memperoleh nilai hasil belajar antara 78 keatas

2. Prestasi belajar sedang, jika peserta didik memperoleh nilai hasil belajar antara 65-78

3. Prestasi belajar rendah, jika peserta didik memperoleh nilai hasil belajar dibawah 65

Pada pengembangan multimedia interaktif ini peneliti lebih menitik beratkan pada hasil belajar siswa dalam ranah kognitif (pengetahuan) dan ranah psikomotoriknya.

D. PEMBAHASAN

1. Pengembangan Multimedia Interaktif pada Pembelajaran AlQur'an Hadis kelas X MA

a. Hasil Studi Pendahuluan

Pengembangan multimedia interaktif Macromedia Flash dalam penelitian ini berawal dari permasalahan- permasalahan yang mendasar yang merupakan unsur terpenting dalam proses pembelajaran di kelas. Adapun permasalahpermasalah yang timbul pada siswa kelas X di MAN I Yogyakarta antara lain siswa malas dalam belajar yakni mereka enggan mendengarkan penjelasan guru didepan kelas karena penyampaiaannya yanng terlalu membosankan. Masalah tersebut dipengaruhi oleh beberapa faktor diantaranya pertama, terbatasnya media pembelajaran yang digunakan 
oleh guru pada saat pembelajaran berlangsung. $^{20}$

Kedua, sebagai sumber bacaan siswa, guru lebih bergantung pada buku ajar tertentu terbitan Kementrian Agama, dan modul "HIKMAH" terbitan Akik Pustaka. Dua sumber tersebut dijadikan sebagai bahan referensi guru dalam mengajar AlQur'an Hadis kelas X di MAN 1 Yogyakarta. Ketiga, pembelajaran AlQur'an Hadis masih terpusat pada guru, hal tersebut ditunjukkan pada pembelajaran yang dilakukan lebih mengarah pada pemberiann pengetahuan dari guru ke siswa. Disamping itu metode ceramah masih mendominasi jalanannya pembelajaran, yakni guru menjelaskan materi sementara siswa mendengarkan penjelasan guru. Menurut Drs. Zuliadi, untuk pembelajaran Al-Qur'an Hadis di MAN 1, pengembangan multimedia interaktif sangat bagus untuk dikembangkan. Beliau juga menuturkan bahwa kurangnya kreativitas guru dalam mengemas materi sendiri, sehingga sumber pengetahuan siswa kurang ${ }^{21}$.

Observasi dilakukan pada hari kamis tanggal 29 November 2017 di MAN 1 Yogyakarta. Pembelajaran berlangsung menggunakan media PowerPoint (PPT) dengan metode ceramah dan tanya jawab antara guru dan siswa, namun hasil yang di

${ }^{20}$ Hasil Observasi Lapangan pada kelas X IPS 1- dan IPS-2 di MAN I Yogyakarta, pada tanggal 29 November 2018.

${ }^{21}$ Hasil wawancara dengan bapak Drs. Zuliadi, M.Ag, guru mata pelajaran Al-Qur'an Hadis kelas X pada tanggal 29 November 2018 dapatkan belum maksimal. Masih terlihat siswa yang kurang aktif bertanya pada guru dan ada sebagian siswa yang mengobrol dan tidur saat pembelajaran. Penggunaan media ini diakui guru belum sepenuhnya membuat siswa ikut berpartisipasi. Sementara perhatian dan partisipasi siswa lainnya masih belum fokus. ${ }^{22}$

Berdasarkan masalah diatas kurangnya penggunaan media pembelajaran interaktif menyebabkan siswa jenuh mendengar penjelasan guru sehingga menjadikan nilai hasil belajar siswa menurut. Media pembelajaran yang digunakan guru saat ini kurang mendapatkan respon positif dari siswa. Sajian materi yang terdapat dalam buku ajar dan modul belum dilengkapi visualisasi yang jelas dan video yang mendukung.

Oleh karena itu pengembangan multimedia interaktif Al-Qur'an Hadis melalui Macromedia Flash dimaksudkan untuk mengatasi kessenjangan antara kondisi ideal dengan kondisi riil dilapangan. Kondisi real yang dimaksudkan adalah (1) tersedianya media pembelajaran melalui multimedia interaktif Macromedia Flash untuk meningkatkan hasil belajar siswa, (2) hadirnya multimedia interaktif ini, untuk dapat melengkapi media pembelajaran sebelumnya sehingga menjadi lebih efektif dan menarik sebagai media pembelajaran di sekolah.

Dari segi isi kondisi riil yang dihadapi kaitannya dengan media pembelajaran Al-Qur'an Hadis di

${ }^{22}$ Hasil Observasi Lapangan di MAN I Yogyakarta, pada tanggal 29 November 2018 
sekolah yakni berupa buku ajar dan modul yang dinilai masih kurang efektif untuk dijadikan sumber belajar. Berdasarkan analisis terhadap kedua sumber buku ajar diatas bahwa pada kedua buku tersebut memuat beberapa dalil- dalil Al-Qur'an dan Hadis dengan penjelasan yang sedikit. Kurangnya kajian terhadap Al-Qur'an baik dari segi tafsiran Ayat, mufrodat (kosa kata), kandungan ayat maupun Hadis. Dalam buku tersebut kurang menggaitkan ayat ayat- Al-Qur'an dan Hadis dalam fenomena kehidupan sehari- hari.

Ilustrasi gambar yang terbatas serta belum dilengkapi dengan multimedia interaktif. Bahasa yang digunakan juga cenderung menggunakan bahasa buku yang kaku dan terkesan kurang komunikatif, sementara yang diharapkan dalam pembelajaran K13 khususnya adalah menggunakan bahasa komunikatif.

Demikianlah terkait ketersediaan pengembangan media pembelajaran yang bisa dilakukan oleh masingmasing guru, dalam studi pendahulu teridentifikasi bahwa guru bidang studi melalui wawancara bahwa mereka merasa kesulitan mengembangkan multimedia interaktif melalui macromedia flash karena membutuhkan waktu yang lama dan kemampuan khusus untuk membuatnya.

b. Hasil Analisis Pembelajaran dan Konteks

Kegiatan dilaksanakan hanya untuk mengidentifikasi ketrampilanketrampilan yang harus dimiliki siswa untuk mencapai suatu tujuan pembelajaran. ketrampilan yang harus dimiliki siswa untuk mencapai suatu pembelajaran disesuaikan dengan Standar Kompetensi Lulusan (SKL) yang ada, baik ketrampilan kognitif, afektif, maupun psikomotoriknya.

Sebelum

peneliti mengembangkan multimedia interaktif, hal yang harus dilakukan sebelumnya adalah mengidentifikasi ketrampilanketrampilan secara spesifik, karakteristik umum, dan pengetahuan awal yang harus dimiliki siswa sehingga mereka siap mengikuti pembelajaran diruang kelas dengan menggunakan media yang dikembangkan.

Dalam pengembangan multimedia interaktif ini, siswa yang memiliki kelebihan dalam bidang teknologi akan merasa tertarik untuk mengikuti pelajaran. Sementara siswa yang lebih menyukai pembelajaran dengan model konvensional keadaan akan berbanding terbalik. Sehingga dalam mengaplikasikan media yang dikembangkan, guru dapat memberikan pengantar materi dengan sedikit menerangkan secara konvensional sebagai selingan dalam pembelajaran menggunakan multimedia interaktif ini.

Oleh karena itu peneliti merancang multimedia interaktif melalui macromedia flash. Interaktif dapat diartikan adanya interaksi, komunikasi siswa dengan guru. Diharapkan siswa dapat memberikan umpan balik pada pembelajaran berlangsung. Ciri khas dari multimedia interaktif yang dikembangkan ini siswa dapat belajar secara mandiri maupun terbimbing, siswa mudah dalam 
pengoperasiannya, dilengkapi dengan simulasi video yang sulit ditampilkan secara nyata, kuis interaktif dan kesimpulan pada materi yang sudah dipelajari.

c. Rumusan Tujuan Khusus

Pada pengembangan multimedia ini tujuan khusus pembelajaran dirumuskan secara spesifik dalam kompetensi inti, kompetensi dasar, dan indikator dari materi Ikhlas dalam beribadah kajian terhadap QS.AlAn'ãm ayat 162-163, QS. Al-Bayyinah ayat 5 dan Hadis Nabi yang diriwayatkan Iman Bukhori dari Aisyah ra.

Indikator:

1. Siswa dapat membaca QS.AlAn'ãm(6): 162-163, alBayyinah(98):5 dan Hadis Bukhari dari Aisyiyah ra.

2. Siswa dapat menyebutkan makna mufrodat QS. Al An'ãm(6): 162163, al-Bayyinah(98):5 dan Hadis Bukhari dari Aisyiyah ra. tentang keikhlasan dalam beribadah

3. Siswa dapat menjelaskan kandungan Al- An’ãm(6): 162163, al-Bayyinah(98):5 dan Hadis Bukhari dari Aisyiyah ra. tentang keikhlasan dalam beribadah

4. Siswa dapat mengaitkan isi kandungan Al- An'ãm(6): 162163, al-Bayyinah(98):5 dan Hadis Bukhari dari Aisyiyah ra. tentang keikhlasan dalam beribadah di kehidupan sehari- hari

5. Siswa dapat menunjukkan perilaku ikhlas dalam beribadah

6. Siswa dapat mengambil manfaat atas perilaku ikhlas dalam beribadah
7. Siswa dapat mengambil hikmah dari perilaku ikhlas dalam beribadah bagi kehidupan.

d. Deskripsi Media Pembelajaran Hasil Pengembangan

Berdasarkan tahapan-tahapan pada pengembangan Dick \& Carey dihasilkan sebuah produk multimedia interaktif hasil pengembangan yakni berupa multimedia interaktif Al-Qur'an Hadis melalui Macromedia Flash materi Ikhlas dalam beribadah kajian QS. Al- An'ãm ayat 162-163, AlBayyinah ayat 5 dan Hadis yang terkait mata pelajaran Al-Qur'an Hadis untuk siswa kelas $\mathrm{X}$ MA. Hasil pengembangan media pembelajaran ini, terdiri dari beberapa komponen: Halaman Cover Depan, Menu, Petunjuk Penggunaan, Halaman Author, Halaman KI/KD dan Indikator, Peta Konsep, Halaman materi (sub materi terdiri dari: Memahami QS. An'ãm ayat 162-163, Memahami QS. Al-Bayyinah ayat 5, Memahami Hadis Nabi tentang ikhlas dalam beribadah, Memahami ikhlas dalam beribadah, Memahami bentuk- bentuk ikhlas dalam ibadah, Perilaku ikhlas dalam ibadah, Hikmah Perilaku Ikhlas dalam Beribadah), halaman kuis, rangkuman, daftar pustaka dan halaman exit.

\section{Paparan Data Hasil Uji Ahli}

a. Ahli Desain Media

Data yang diperoleh merupakan data kuantitatif dan data kualitatif. Data kuantitatif berasal dari angkat penilaian dengan skala linkert, sedangkan data kualitatif berupa penilaian tambahan atau saran dari validator. Hasil analisi butir dari ahli desain media menyatakan bahwa valid dan hanya 
beberapa poin yang perlu direvisi. Menurut ahli desain media, bahwa produk multimedia interaktif melalui Macromedia Flash telah memenuhi kriteria sebagai multimedia interaktif yang siap diujikan di lapangan dengan prosentase kevalidan sebesar $88 \%$.

Hasil saran dan komentar ahli media pembelajaran diatas menunjukkan bahwa dalam pengembangan multimedia interaktif Al-Qur'an Hadis kelas X materi "Ikhlas dalam beribadah" masih perlu dilakukan sedikit revisi khususnya pada konten kuis yakni dengan memindahkan jawaban benar yang terdapat diakhir kuis diletakkan menjadi jawaban benar di tiap- tiap soal. Jadi penggguna/ siswa dapat secara langsung melihat jawaban yang benar.

Kemudian, terkait saran untuk memjadikan file yang lebih kecil sehingga mudah diakses melalui android belum bisa dilakukan oleh pengembang. Hal tersebut belum bisa dilakukan karena mulai awal pembuatannya media pembelajaran ini dirancang untuk PC bukan android. Disamping itu bahan yang digunakan untuk menyusun media memiliki size yang besar dan jika diperkecil dapat merusak tampilan media tersebut.

Semua data dari hasil angket penilaian dan diskusi dengan ahli media pembelajaran dijadikan landasan untuk menyempurnakan komponen media pembelajaran Al-Qur'an Hadis kelas X MA materi "Ikhlas dalam beribadah". Menurut hasil validasi ahli media pembelajaran diatas bahwa multimedia interaktif Al-Qur'an Hadis materi ikhlas dalam beribadah layak untuk di uji cobakan di lapangan.

\section{b. Ahli Materi}

Data yang diperoleh merupakan data kuantitatif dan data kualitatif. Data kuantitatif berasal dari angkat penilaian dengan skala linkert, sedangkan data kualitatif berupa penilaian tambahan atau saran dari validator. Hasil analisi butir dari ahli materi menyatakan bahwa valid dan hanya beberapa poin yang perlu direvisi. Menurut ahli materi, bahwa produk multimedia interaktif melalui Macromedia Flash telah memenuhi kriteria sebagai multimedia interaktif yang siap diujikan di lapangan dengan prosentase kevalidan sebesar $98.75 \%$.

Data kualitatif hasil validasi ahli materi diambil dari saran, dan komentar yang diberikan oleh validator ahli materi melalui kolom kritik dan saran yang tertera dalam angket mengenai isi materi yang terdapat pada media pembelajaran Al-Qur'an Hadis kelas X MA materi Ikhlas dalam Beribadah. Masukan, saran, dan komentar disajikan dalam pernyataan terbuka.

Semua data kualitatif merupakan catatan ahli materi pada kolom saran/ komentar yang terdapat pada angket dan hasil diskusi panjang yang telah diolah dan disusun oleh pengembang dalam tabel diatas. Dari data kuantitatif dan kualitatif diatas akan dijadikan landasan untuk menyempurnakan komponen media pembelajaran AlQur'an Hadis kelas X MA materi Ikhlas dalam beribadah. Hasil dari penyempurnaan media pembelajaran Al-Qur'an Hadis kelas X MA ini 
kemudian akan diuji cobakan di lapangan. melihat hasil validasi diatas dengan berbagai catatan penyempurnaan akan tetapi media pembelajaran tersebut sepenuhnya telah layak diuji cobakan di lapangan dengan syarat melakukan revisi terlebih dahulu.

\section{c. Ahli Bidang Studi}

Berdasarkan data angket hasil validasi guru mata pelajaran Al-Qur'an Hadis terhadap produk pengembangan multimedia interaktif Al-Qur'an Hadis materi Ikhlas dalam Beribadah untuk kelas X MA mendapatkan hasil yang baik, dengan prosentase kevalidan sebesar $91.25 \%$.

keseluruhan pengembangan multimedia interaktif pada pembelajaran Al-Qur'an Hadis baik dan layak untuk di uji coba lapangan. Menurut beliau, mengingat belum pernah ada sebelumnya dilakukan pengembangan multimedia interaktif khususnya Al-Qur'an Hadis di MAN 1 Yogyakarta. Disamping itu, menurut beliau pengembangan multimedia interaktif ini sesuai dengan kurikulum yang ada disekolah yakni Kurikulum 2013.

Terdapat inovasi baru dalam pengembangan media pembelajaran yang sebelumnya hanya menggunakan buku ajar terbitan Kementerian Agama tahun 2014, LKS Hiknah, PPT dari guru yang bersifat terbatas yakni berupa uraian singkat, serta media lain yang mendukung seperti papan tulis, spidol dan buku tulis. Dengan Adanya pengembangan sebuah media pembelajaran yang berbasis multimedia interaktif yang bersifat audio-visual ini tentunya lebih memanfaatkan LCD serta sound system sebagai sarana yang memadai di kelas. Hal tersebut secara tidak langsung menarik perhatian dan minat siswa untuk belajar Al-Qur'an Hadis.

Pengembangan multimedia interaktif pada pembelajaran AlQur'an Hadis kelas X MA materi Ikhlas dalam beribadah melalui program Macromedia Flash tersusun dengan rapi dan mudah dipelajari sehingga memudahkan siswa untuk memahami materi Ikhlas dalam beribadah. Dilengkapi dengan video ilustrasi sebagai gambaran contoh perilaku ikhlas dalam beribadah diharapkan mampu memahamkan kepada siswa perbuatan ikhlas dalam kehidupan sehari- hari sehingga menjadikan materi tersebut hidup, maksudnya tidak hanya sampai pada pemahaman terhadap teori saja akan tetapi faham terhadap hal- hal yang praktis.

Semua data dari hasil review dan wawancara dengan guru bidang studi Al-Qur'an Hadis diatas membuktikan bahwa pengembangan multimedia interaktif Al-Qur'an Hadis materi ikhlas dalam beribadah kelas $\mathrm{X}$ MA di MAN 1 Yogyakarta dijadikan landasan untuk penyempurnaan produk pengembangan multimedia interaktif sebelum diuji cobakan pada uji coba lapangan.

\section{Uji efektifitas Multimedia interaktif.}

Berdasarkan uji efektifitas di lapangan, hasil uji perorangan dengan responden 4 siswa dari kelas X MAN I Yogyakarta mendapatkan prosentase 
sebesar $95 \%$ yang berarti valid. Hasil uji kelompok kecil yang terdiri dari 10 responden mendapatkan prosentase sebesar Keduapuluh poin pernyataan angket diatas menghasilkan rata- rata prosentase $93.4 \%$ yang berarti sangat valid kecuali nomer 11 dan 14 menyatakan valid dengan prosentase keduanya sebesar 82,5\%, yakni indikator tentang fungsi tombol navigasi dan kelengkapan menu dalam multimedia interaktif pada pembelajaran Al-Qur'an Hadis materi ikhlas dalam beribadah kelas X MA.

Produk hasil pengembangan multimedia interaktif pada pembelajaran Al-Qur'an Hadis materi keikhlasan dalam beribadah kelas $\mathrm{X}$ MA setelah menjalani beberapa uji validitas kepada ahli, uji perorangan dan uji kelompok kecil dan telah mengalami berbagai macam revisi, tahapan terakhir yakni melakukan uji coba lapangan atau kelompok besar. Hal tersebut dilakukan untuk mengetahui efektivitas multimedia interaktif lama dengan multimedia interaktif yang baru. Indikator efektivitas multimedia interaktif hasil pengembangan ini yakni pemahaman siswa lebih tinggi, siswa lebih aktif dan hasil belajar meningkat.

Untuk menguji keefektifan media yang dikembangkan, peneliti menggunakan desain eksperimen kelompok control preetes-postes (Pretest-Posttest Control Group Design). Peneliti memilih kelompok kontrol yakni kelas IPS-1 dan kelompok eksperimen yakni kelas IPS2. Dua kelompok tersebut dipilih langsung yang masing- masing kelas berjumlah 25 siswa.

Kelas eksperimen diberi perlakuan dengan menggunakan produk multimedia interaktif pada pembelajaran Al-Qur'an Hadis materi ikhlas dalam beribadah kelas X MA melalui Macromedia Flash, sedangkan kelas kontrol tetap menggunakan media lama yakni PPT dari guru yang didukung buku ajar dan LKS. Setelah selesai perlakuan, kedua kelas diberi posttest. Peneliti memberikan pretest untuk mengetahui hasil belajar awal, kemudian melakukan posttest setelah peneliti memberikan perlakuan eksperimental, yaitu menggunakan media pengembangan.

Kedua kelas tersebut diberikan soal pree-test untuk mengetahui pengetahuan awal, adakah perbedaan pengetahuan awal antara kelas IPS-1 sebagai kelas kontrol dan kelas IPS-2 sebagai kelas eksperimen. Berikut hasil penghitungan melalui SPPS untuk mengetahui apakah ada perbedaan pengetahuan awal antara kelas kontrol dan kelas eksperimen. Sebelum melakukan uji keefektifan, ada beberapa tahapan uji statistik yang harus dilakukan peneliti diantaranya: uji normalitas dan uji homogenitas.

Multimedia interaktif melalui macromedia flash pada pembelajaran Al-Qur'an Hadis materi ikhlas dalam beribadah kelas X MA telah selesai dikembangkan dan di validasi baik oleh ahli media, ahli materi, dan juga guru mata pelajaran Al-Qur'an Hadis kelas $\mathrm{X}$ MA. Pengembangan multimedia interaktif ini telah melalui beberapa tahapan penelitian pengembangan. 
Pada awalnya produk pengembangan multimedia interaktif diawali dengan pembuatan produk awal yang didasarkan pada analisis kebutuhan pengembangan multimedia interaktif pembelajaran Al-Qur'an Hadis kelas X MA.

Kemudian dilakukan evaluasi melalui validasi dan beberapa tahapan uji coba. Tahapan validasi dilakukan oleh ahli media, ahli materi dan guru mata pelajaran Al-Qur'an Hadis. Tahapan uji coba dilakukan oleh uji perorangan, uji kelompok kecil dan uji lapangan (kelompok besar).

Data hasil validasi ahli media, ahli materi dan guru mata pelajaran AlQur'an Hadis digunakan untuk melakukan revisi pada tahapan awal, kemudian hasil revisi ini digunakan untuk uji coba perorangan dan uji coba kelompok kecil (terbatas). Data hasil uji coba kelompok kecil digunakan untuk merevisi produk sebelum diuji cobakan dalam uji coba lapangan.

Hasil pengembangan multimedia interaktif pada pembelajaran Al-Qur'an Hadis materi ikhlas dalam beribadah kelas X MA yakni berupa multimedia interaktif melalui macromedia flash yang dikemas dalam CD (Compact Disk) yang dapat digunakan melalui komputer/ leptop.

Secara umum produk yang dikembangkan oleh peneliti ini memiliki beberapa kelebihan dan kelemahan. Adapun kelebihan dan kelemahan produk ini antara lain sebagai berikut:

1. Kelebihan

a. Multimedia interaktif pada pembelajaran Al-Qur'an Hadis materi ikhlas dalam beribadah kelas $\mathrm{X}$ MA ini merupakan multimedia interaktif berbasis audio- visual, yang cocok jika digunakan untuk pembelajaran dengan pendekatan konstruktivistik yang menekankan pada proses belajar dengan membangun interaksi antara siswa dengan lingkungannya melalui proses pengalaman- pengalaman belajar untuk memperoleh pengalaman baru.

b. Multimedia interaktif ini didesain sesuai dengan karakteristik siswa serta dapat digunakan secara mandiri.

c. Pada pembelajaran Al-Qur'an hadis, multimedia interaktif ini mampu membantu siswa dalam meningkatkan kemampuan kognitif serta psikomotoriknya.

d. Multimedia interaktif ini dilengkapi dengan video serta gambar- gambar yang menarik untuk menvisualisasikan materi sehingga terkesan lebih hidup dan menyentuh.

e. Multimedia interaktif ini dilengkapi dengan evaluasi dalam bentuk kuis interaktif sehingga siswa dapat secara langsung menginput jawaban, mengetahui status jawaban benar arau salah serta diakhir siswa dapat mengetahui perolehan nilai secara langsung.

f. Produk multimedia interaktif pada pembelajaran Al-Qur'an Hadis ini mengubah paradigma belajar yang dulunya teacher center menjadi student center, yakni guru hanya 
sekedar vasilitator saja sedangkan siswa yang menjadi pusat belajarnya.

2. Kekurangan

a. Multimedia interaktif ini belum mampu untuk meningkatkan kompetensi spiritual dan sikap (tingkah laku) siswa, karena konten dalam multimedia ini berada pada

b. Cakupan materi yang dikembangkan kurang luas karena hanya sebagian dari materi semester genap saja.

c. Multimedia interaktif ini hanya bisa digunakan di komputer/ leptop saja dan belum bisa diakses melalui handphone android, karena resolusinya yang besar sehingga tidak bisa dibuka di handphone.

d. Membutuhkan waktu yang cukup lama untuk membuatnya sehingga membutuhkan ketekunan dan keuletan serta skill khusus. Perlunya aplikasi komputer untuk membuatnya.

Selain kelebihan dan kekurangan dari pengembangan media pembelajaran ini, pengembang memberikan tawaran yakni sebagai berikut:

1. Pada umumnya produk ini dapat memberikan suasana yang lebih hidup, tampilan yang lebih menarik dan dapat memperlihatkan proses yang lebih nyata. Disamping itu juga hemat waktu,biaya dan dapat digunakan kapan saja dan dimana saja.

2. Produk ini lebih efektif jika digunakan oleh sekolah yang memiliki fasilitas yang mendukung

seperti LCD, Leptop/komputer, dan sound, karena akan mempernudah dalam proses pembelajaran.

3. Produk ini juga lebih efektif jika digunakan oleh guru yang memiliki skill khusus dalam mengamplikasikan komputer sehingga guru bisa dengan mudah mengembangkan materi yang ada dalam produk atau menambah materi yang ada dalam produk media pembelajaran jika terdapat materi yang kurang.

\section{E. KESIMPULAN}

Pengembangan multimedia interaktif pada pembelajaran Al-Qur'an Hadis materi keikhlasan dalam beribadah untuk kelas X MA semester genap, dikembangkan menggunakan model pengembangan Dick \& Carey dengan sepuluh langkahnya. Jika diambil garis besarnya kesepuluh langkah tersebut mencakup empat hal yakni tahap eksplorasi, tahap pengembangan, tahap validasi dan uji lapangan. Hasil pengembangan multimedia interaktif menghasilkan produk multimedia interaktif AlQur'an hadis materi ikhlas dalam beribadah kelas X MA yang dibuat melalui aplikasi macromedia flash. Produk multimedia interaktif tersebut dikemas dalam CD (Compact disk) yakni berupa file portable sehingga dapat digunakan kapanpun dan dimanapun. Produk multimedia yang dikembangkan telah memenuhi komponen sebagai multimedia pembelajaran Al-Qur'an Hadis yang 
baik dan dapat digunakan untuk meningkatkan hasil belajar siswa.

1. Berdasarkan hasil validasi ke ahli media, ahli materi dan guru mata pelajaran Al-Qur'an Hadis bahwa produk pengembangan multimedia interaktif pada pembelajaran AlQur'an Hadis materi ikhlas dalam beribadah kelas $\mathrm{X}$ MA layak digunakan sebagai media pembelajaran di sekolah. Hasil validasi ahli media mendapatkan prosentase sebesar 88\%, ahli materi dengan prosentase $98.75 \%$, dan validasi guru mata pelajaran Al-Qur'an Hadis dengan prosentase sebesar $91,25 \%$.

2. Berdasarkan hasil uji coba multimedia interaktif pada pembelajaran Al-Qur'an Hadis menghasilkan tingkat keefektifan yang tinggi berdasarkan tiga kali pengujian dilapangan pada siswa kelas X MA yakni uji perorangan dengan hasil prosentase mencapai 95\%, uji kelompok kecil dengan hasil prosentase mencapai $93.8 \%$ dan uji coba lapangan (kelompok besar) peneliti menggunakan kelas esperimen dan kelas kontrol. Pada penelitian ini didapatkan hasil bahwa kelas yang menggunakan produk media pembelajaran AlQur'an Hadis nilai hasil belajarnya pada materi ikhlas dalam beribadah melalui penghitungan uji T-Test mendapatkan hasil yang lebih tinggi dari pada kelas yang tanpa media pembelajaran dengan sig. Sebesar 0,971.

\section{DAFTAR PUSTAKA}

Andi, Andreas, Menguasai Pembuatan Animasi dengan Macromedia Flash. Jakarta: PT. Elex Media Komputindo, 2003

Ardiansyah, Nurdin, Macromedia

Flash Profesional 8: Sebuah Tutorial Flash untuk Pemula. Kalimantan Barat: Sekadau, 2013.

Bambang, Wiyono dan Sunarni, Evaluasi Program Pendidikan dan Pembelajaran Malang:

Fakultas Ilmu Pendidikan Universitas Negeri Malang, 2009.

Dalyono, M, Psikologi Pendidikan. Jakarta: Rinneka Cipta, 1997.

Darmawan, Deni, Teknologi Pembelajaran. Bandung: RosdaKarya, 2011.

Daryanto, Media Pembelajaran: Peranananya sangat Pengting dalam Mencapai tujuan Pembelajaran Yogyakarta:Gava Media, 2010.

Emzir, Metologi Penelitian Pendidikan Kuantitatif dan Kualitatif, PT. Raja Grafindo Persada: Jakarta, 2015.

Hamalik, Oemar, Media Pendidikan. Bandung: PT. Citra Aditya Bakti, 1994.

Hasil Observasi Lapangan di MAN I Yogyakarta, pada tanggal 28 November 2017

Hasil wawancara dengan Bapak Muh. Najib Asyraf,Lc.M.Ag, guru mata pelajaran Qur'an Hadis kelas $\mathrm{X}$ pada tanggal 28 November 2017 
Hasil wawancara dengan Bapak Drs. Zuliadi,M.Ag guru mata pelajaran Qur'an Hadis kelas X pada tanggal 28 November 2017

Khairani, Majidah, "Pengembangan Media Pembelajaran dalam Bentuk Macromedia Flash Materi Tabung Untuk SMP Kelas IX" dalam Jurnal IPTEKS TERAPAN Research of Applied Science and Education Vol.10. No. 2 diakses melalui http ://ejournal. kopertis10 .or. id, 2016.

Kustandi, Cecep dan Bambang.S. Media Pembelajaran Manual dan Digital. Bogor: Ghalia Indonesia

Lampiran Keputusan Menteri Agama Republik Indonesia, No.165 Tahun 2014 tentang tentang Kurikulum Madrasah 2013 Pendidikan Agama Islam dan Bahasa Arab, Pdf.

Munir, Multimedia: Konsep \& Aplikasi dalam Pendidikan. Bandung: Alfabeta, 2015.

Nasir, Muhammad, Pengembangan Model Pembelajaran Al-Qur'an Hadis Madrasah Aliyah (MA) di Samarinda dalam jurnal "AlQalam" Vol.20 No1, 2014.

Nassar, Merancang Pembelajaran Aktif dan Kontekstual. Jakarta: Grasindo, 2006.

Prastowo, Aris, Pengembangan Media Pembelajaran Berbasis Macromedia Flash 8 pada Kompetensi Dasar Mengidentifikasi Kelistrikan dan Instrumen Sepeda Motor untuk siswa kelas XI Jurusan Teknik Otomotif Sepeda Motor di SMK Negeri 9 Malang, Jurnal Teknik Mesin Vol.22, No.2. 2014.

Rahman, Taufik (Kontributor Pamekasan), Penganiayaan Guru Oleh Siswa di Sampang Begini Kronologinya.. dilansir pada laman www.kompas.com, 2018.

Rasyid, Harun dan Mansur, Penilaian Hasil Belajar Bandung:Wacana Prima, 2008.

Rohendi, Dedi, "Efektivitas Pembelajaran Multimedia Interaktif Berbasis Konteks Terhadap Hasil Belajar Siswa pada Mata Pelajaran TIK", dalam Jurnal PendidikanBandung: UPI. diakses dari http://jurnal.upi.edu. 2010

Sadiman, Arief S, Media Pendidikan: Pengertian, Pengembangan dan Pemanfaatannya. Jakarta: Raja Grafindo, 2014.

Sanaky, Hujair AH. Media Pembelajaran, Yogyakarta: Safiria Insani Press, 2009.

Sari, Restina Fatma. Pengembangan Media Pembelajaran Aqidah Akhlak Berbasis Multimedia Interktif untuk Siswa MI di Kulon Progo. Yogyakarta:Program Pasca Sarjana UIN Sunan Kalijaga, 2013.

Setyosari, Punaji. Metode Penelitian Pendidikan dan pengembangan.ed 2. Jakarta:Kencana, 2012. 
Sudijono, Anas, Pengantar Evaluasi Pendidikan, Jakarta: PT. Raja Grafindo Persada, 2011.

Sudjana, Nana. Penilaian Hasil Proses Belajar Mengajar, Bandung:Rosdakarya, 2014.

Sugiyono, Metode Penelitian Kuantitatif Kualitatif dan $R \& D$, Bandung: Alfabeta, 2011.

Sugiyono, Metode Penelitian

Pendidikan, Pendekatan

Kuantitatif, Kualitatif, dan R\&D Bandung: ALfabeta, 2016.

Sukiman, Pengembangan Media Pembelajaran. Yogyakarta: Pustaka Insani Madani, 2012.

Sukmadinata, Nana Syaodih, DasarDasar Proses BelajarMengajar. Bandung: Sinar Baru Algesindo. 2003.

Sukmadinata, Nana Syaodih, Metode Penelitian Pendidikan,

Bandung: PT. Remaja Rosdakarya, 2011.

Turmudi. Metode Statistika, Malang: UIN- Press, 2008. 
